\title{
Progressionsmodel: Entreprenørskabs- og innovationsundervisning
}

Nicolai Nybye, cand.mag., Teamet for Videregående Uddannelser, Fonden for Entreprenørskab - Young Enterprise.

Anders Rasmussen, cand.pæd., Teamet for Grundskoler, Fonden for Entreprenørskab - Young Enterprise.

Artiklen tager afsæt $i$ en forståelse af entreprenørskab, som en praksisform, hvor muligheder og idéer omsættes til enten økonomisk, kulturel eller social værdi. Denne forstålse kædes sammen med behovet for, at elever og studerende lærer at agere $i$ forskellige omverdenssammenhænge og her kan skabe værdi. Artiklen peger på behovet for at kunne operationalisere tilgangen til entreprenørskab i form af eksplicitte undervisningsdimensioner og læringsmål. Artiklen præsenterer således en progressionsforståelse, der giver en teoretisk optik på den sammenhængende udvikling af læringsmål for elever og studerendes entreprenørskabs- og innovationsviden og kompetencer igennem uddannelsesforløbet, og den peger på en forståelse, der indlejrer entreprenørskab $i$ kernefagligheder og $i$ de studerendes deltagelse $i$ erfaringsskabende processer. Artiklen er skrevet med udgangspunkt $i$ Fonden for Entreprenørskab - Young Enterprise, der understøttes af de fire ministerier, der danner det nationale Partnerskab for Uddannelse $i$ Entreprenørskab. Artiklen har i foråret 2013 været $i$ høring hos en række lærere, undervisere og forskere $i$ det danske uddannelsessystem inden offentliggørelsen i sommeren 2013.

\section{Indledning}

Med baggrund i globalisering og store forandringer i samfund, økonomi, arbejdsmarked og beskæftigelsessituation er der over det meste af verden etableret en ambition om at integrere entreprenørskab og innovation i skole og uddannelsessystem. Også i Danmark er det et strategisk mål, at entreprenørskab og innovation skal integreres i uddannelsessystemet ${ }^{1} \mathrm{og}$ indgå som en rød tråd fra grundskole til afsluttet

\footnotetext{
${ }^{1}$ Ministeriet for Forskning, Innovation og Videregående Uddannelse. (Dec. 2012). Danmark Løsningernes land. Styrket samarbejde og bedre rammer for innovation i virksomhederne; Ministeriet for Videnskab, Teknologi og Udvikling. Økonomi- og Erhvervsministeriet. Undervisningsministeriet. Kulturministeriet. (Nov. 2009). Strategi for uddannelse i entreprenørskab.
} 
uddannelsesforløb, - fra $A B C$ til ph.d. (Moberg et al., 2013). Dette har medført, at udbuddet af og deltagelse i entreprenørskabs- og innovationsundervisning er steget på alle uddannelsesniveauer (Blenker et al., 2011; Vestergaard et al., 2013).

Samtidig udvider forståelsen af entreprenørskabsbegrebet sig. Fra alene at være tæt forbundet med opstart af virksomhed, har begrebet fået en bredere betydning (Fayolle \& Gailly, 2008) og omfatter både socialt og kulturelt entreprenørskab. ${ }^{2}$ Således fremstår formålet med entreprenørskabs- og innovationsundervisning komplekst, og skal bibringe elever og studerende viden og kompetencer, der kan anvendes i mange forskellige sammenhænge (Pittaway \& Cope, 2007; Surlemont, 2009; Gibb, 2010; Neck \& Greene, 2011). Entreprenørskabs- og innovationsundervisningen bliver således en del af et fremtidsrettet dannelsesideal, som skal give elever og studerende kompetencer til at se muligheder og skabe værdi i bred forstand. Samtidig skal entreprenørskabsundervisningen give elever og studerende redskaber til at kunne håndtere de mange udfordringer, der er forbundet med at være menneske i en globaliseret og foranderlig verden (Baumann, 2000; Giddens, 1991; Gibb, 2010; Venkataraman et al., 2012). Udvidelsen af begrebet påvirker derfor formålet med innovations- og entreprenørskabsundervisning, der her defineres bredt som:

- At give den enkelte mulighed for og redskaber til at forme sit eget liv

- At uddanne engagerede og ansvarstagende medborgere

- At udvikle viden og ambitioner om at etablere virksomheder og arbejdspladser

- At øge kreativitet og innovation i eksisterende organisationer

- At skabe vækst, udvikling og velfærd

For at operationalisere dette komplekse formål etablerer vi i det følgende en progressionsmodel, der kan eksplicitere innovation og entreprenørskab som læringsmål på forskellige niveauer i uddannelsessystemet. Ambitionen er at sikre en fælles begrebsforståelse såvel som en forståelse af progressionen i læringsmål og af den entreprenørielle og innovative dannelse, der følger af, at læringsmålene udfoldes som undervisning.

Nærværende progressionsmodel skal imødekomme denne ambition og foreskriver en sammenhængende udvikling af læringsmål for elever og studerendes entreprenørskabs- og innovationsviden og kompetencer igennem uddannelsesforløbet - betragtet som en samlet og kontinuerlig indsats i et mangfoldigt skole- og uddannel-

\footnotetext{
${ }_{2}^{2}$ Den bredere betydning ses fx i Fonden for Entreprenørskab - Young Enterprises definition af entreprenørskab: Entreprenørskab er, når der bliver handlet på muligheder og gode idéer, og disse bliver omsat til værdi for andre. Den værdi, der skabes, kan være af økonomisk, kulturel eller social art (Vestergaard et al., 2013).
} 
sessystem. Progressionsmodellen er et teoretisk bud, hvis gyldighed må afprøves i forhold til praksis. Den danner således afsæt for dialog og for involvering af nye perspektiver med henblik på den fremtidige udvikling af progression og læringsmål.

\section{Modellens teoretiske afsæt}

I takt med at entreprenørskab og innovation i stigende grad indgår i målet for uddannelse over hele verden, er forskningen på området intensiveret. På trods af dette er der endnu ikke en konsistent eller entydig viden om, hvilke former for entreprenørskabsundervisning, som har hvilke effekter. Dette skyldes dels manglen på longitudinelle undersøgelser, dels en kompleks sammenhæng imellem indhold og form, dels usikkerhed omkring, hvad målet med en sådan undervisning er (Fiet, 2001a, 2001b; Honig, 2004). Således er der over tid etableret flere forskellige paradigmer i entreprenørskabsundervisningen. Disse strækker sig fra en kausal og lineær planlægningsforståelse over en tilgang, der fokuserer på elever og studerendes 'mindset', til en processuel iværksættende og metodisk tilgang (Neck \& Greene, 2011; Sarasvathy, 2001; Sarasvathy \& Venkataraman, 2011; Blenker et al., 2011). Entreprenørskabsog innovationsundervisning har således en mangfoldighed af tilgange, metoder og praksisser.

Inden for paradigmer og forskning på området er der imidlertid en række centrale dimensioner, der træder frem som overordnede forudsætninger for at etablere en funktionel forståelse af entreprenørskabs- og innovationsundervisning. Et centralt perspektiv er fx betoningen af handlingsaspektet, og at entreprenørskabsundervisning skal baseres på elever og studerendes udførende handlinger (Sarasvathy, 2008; Schumpeter, 1911/1934, 1942; Swedberg, 2000; Kirketerp, 2010). Et andet centralt element er udviklingen af kreativitet, evnen til at få idéer, se og skabe muligheder samt evnen til problemløsning (De Bono, 1992; Dyer et al., 2011; Byrge \& Hansen, 2010; Guildford, 1950; Tanggaard, 2008). Opmærksomhed er også knyttet til interaktion med omverden ved $\mathrm{fx}$ at fremhæve samarbejde med forskellige eksterne parter og interessenter samt forståelse af kontekst og kultur i en given sammenhæng (Nielsen et al., 2009; Honig \& Karlsson, 2004; Darsø, 2011). Endelig omhandler et fjerde aspekt elever og studerendes tro på og tillid til egne muligheder for og evner til at kunne agere entreprenørielt (Blenker et al., 2011). Dette fjerde tema er ofte sammenfattet af Banduras (1995) begreb 'self efficacy'.

På denne baggrund tilbyder progressionsmodellen en optik med fire komplementære og indbyrdes afhængige dimensioner: Handling, kreativitet, omverdensforståelse og personlig indstilling. De fire dimensioner defineres efterfølgende og repræsenterer således en teoretisk forståelsesramme for det særligt entreprenørielle og innovative i forskellige undervisningssammenhænge. 
Handling. Handling forstås som en elevs eller studerendes evne og lyst til at iværksætte værdiskabende initiativer samt evnerne til at virkeliggøre disse initiativer gennem samarbejde, netværk og partnerskaber (Kirketerp, 2010; Venkataraman et al., 2012; Sarasvathy \& Venkataraman, 2011; West, 2004). Det er samtidig evnen til at kommunikere formålsrettet og at kunne organisere, målsætte, planlægge og lede aktiviteter. Handlingsdimensionen omfatter ligeledes evnen til at kunne analysere og håndtere risici (Knight, 1921).

Kreativitet. Kreativitet forstås som evnen til både at se og skabe ideer og muligheder (Shane \& Venkataraman, 2000). Det er ligeledes evnen til at kombinere viden, erfaringer og personlige ressourcer fra forskellige områder på nye måder (Sarasvathy, 2001; Herlau \& Tetzschner, 2004). Kreativitet er også evnen til at skabe og revidere personlige forestillinger, eksperimentere og improvisere for at løse problemer og udfordringer (Tanggaard, 2010).

Omverdensforståelse. Omverdensforståelse forstås som viden om- og forståelse af verden, lokalt og globalt. Ligeledes er det evnen til at kunne analysere en kontekst socialt, kulturelt og økonomisk som en arena for værdiskabende handlinger og aktiviteter (Venkataraman et al., 2012). Omverdensforståelse handler også om viden og forståelse for globale problemstillinger i forhold til eksempelvis bæredygtighed, klima og ressourcer.

Personlig indstilling. Personlig indstilling er de personlige og subjektive ressourcer, som elever og studerende møder udfordringer og opgaver med. Det er troen på at kunne agere i verden og herigennem at kunne realisere drømme og planer (Pajares, 1996). Personlig indstilling bygger på evnen til at kunne arbejde vedholdende og overkomme ambivalens, usikkerhed og kompleksitet. Det er ligeledes evnen til at kunne acceptere og lære af andres og egne fejl (Kirketerp, 2010; Detienne \& Chandler, 2004) og at kunne foretage etiske vurderinger og refleksioner.

I den grafiske model nedenfor er de fire entreprenørielle dimensioner indlejret $\mathrm{i}$ et samspil med grund- og kernefaglighed. De fire dimensioner baseres dermed på skolens og uddannelsernes grund- og kernefaglighed, afhængig af uddannelsesniveau og retning. 


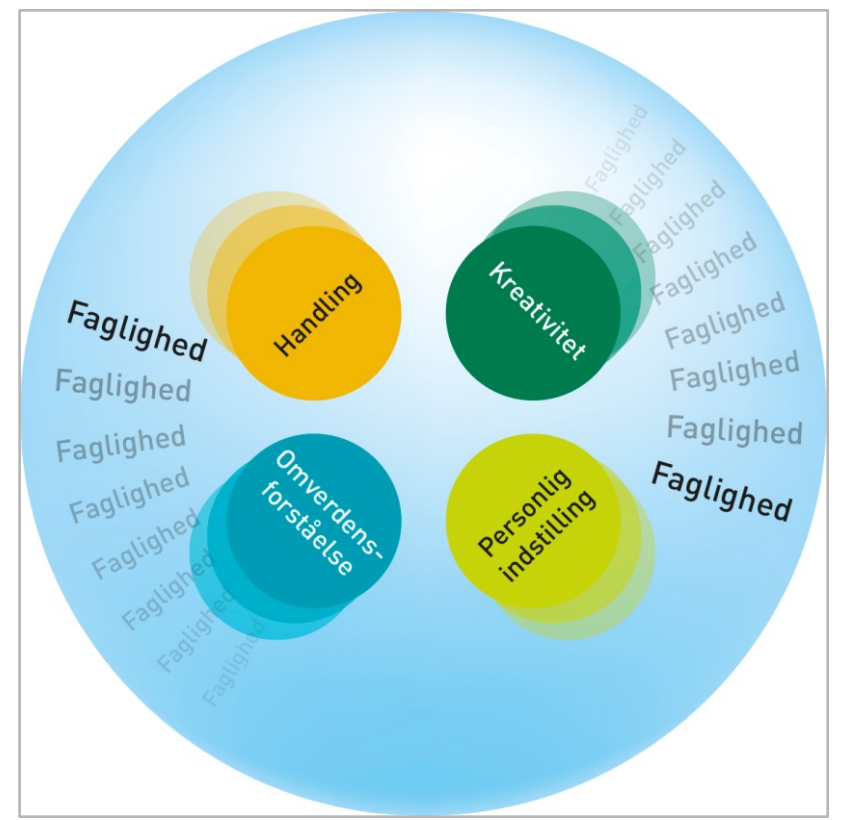

Figur 1: Progressionsmodellen.

I modellen forstås entreprenørskabsundervisning som en integreret del af undervisning og uddannelse, baseret på den enkelte skoles og uddannelsesinstitutions mål og indhold. Dermed fremhæves en præmis om, at forskellige grund- og kernefagligheder vil forme de fire dimensioner. Der vil inden for fag, professioner og studieretninger qua deres forskellige kernefaglige fokus, fremkomme variationer i måden, dimensionerne konkret udfoldes på og bliver til fx social, økonomisk eller kulturel værdi. Det er således en ambition, at alle elever og studerende får innovative og entreprenørielle kompetencer, ikke at alle kan det samme eller har lært det i samme form. I modellen er de fire dimensioner placeret, så de kan udfoldes hver for sig i undervisningen. Dimensionerne er imidlertid indbyrdes forbundne, og de bør derfor, og særligt i undervisning der rummer entreprenørielle processer, indgå i et samspil med hinanden.

Modellen danner på denne baggrund en optik, der kan anvendes som:

- Et billede på den enkelte elevs og studerendes entreprenørielle udvikling og dannelse. Modellen kan afspejle, hvordan den enkelte elev og studerende gennem uddannelsen har erhvervet viden og kompetencer inden for dimensionerne i tæt sammenhæng med det grund- og kernefaglige.

- Et afsæt i forbindelse med evaluering og udvikling af fag og indhold. I den forstand er modellen en optik til selviagttagelse, som skoler og uddannelsesinstitutioner kan benytte til at afsøge, hvordan de fire dimensioner er og bliver en del af uddannelsen.

- Udgangspunkt for udvikling af nye former for test og eksamener. Modellen kan anvendes som en samlende referenceramme i dette arbejde, så udprøvningsformerne understøtter hinanden igennem uddannelsesforløbet. 


\section{Progression}

For at styrke de fire dimensioner i sammenhæng med skolens og uddannelsernes grund- og kernefaglighed igennem uddannelsessystemet, er det centralt, at elever og studerende etablerer kontinuerte erfaringer med værdiskabende innovative og entreprenørielle processer som en del af undervisningen. Erfaringsbegrebet er her anvendt med henvisning til, at det er den personlige aktive involvering i processer og oplevelsen af sammenhænge imellem teori og praksis, der binder de fire dimensioner, grund- og kernefaglighed sammen.

Elever og studerende kan gennem erfaringsdannelsen refleksivt forholde sig til den innovative og entreprenørielle praksis, der er resultatet af de aktiviteter, som de fire dimensioner åbner for. Kontinuerte entreprenørielle og innovative erfaringer fungerer derved som et fundament for individets fremtidige handling, refleksion og læring (Dewey, 1916, 1933; Elkjær, 2009).

Progression i entreprenørskabsundervisning og dannelse sker således ikke udelukkende gennem mere viden om innovation- og entreprenørskab. Den finder sted gennem sammenhængen mellem voksende grund- og kernefaglighed igennem uddannelsen, mere innovations- og entreprenørskabsundervisning og flere og mere omfattende erfaringer med innovation og entreprenørielle processer.

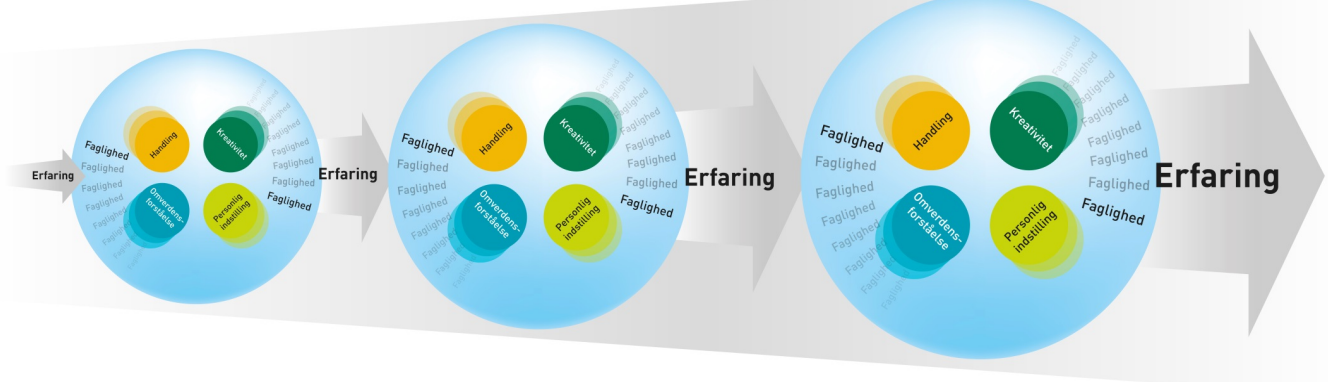

Figur 2: Progression i entreprenørskabsundervisning.

Den grafiske illustration er en model, som både ekspanderer i forhold til vidensdybde og omfang, og illustrerer ligeledes, at de fire entreprenørielle dimensioner er en vigtig del af hele uddannelsesforløbet. Samtidig illustrerer modellen, hvordan der gennem uddannelsesforløbet opbygges stadig flere og mere omfattende erfaringer med innovation og entreprenørielle processer.

De fire entreprenørielle dimensioner i undervisningen vil forandre sig over tid. Fra indskolingselevernes møde med det kendte og nære i lokalområde og familie, til de voksne studerendes involvering i komplekse udfordringer og situationer, der vil udfordre behovet for viden og refleksioner. Ligeledes er mulighederne for handling og for selvstændigt at iværksætte værdiskabende projekter forskellige fra niveau til 
niveau. Kreativitet og evnen til at forholde sig skabende og løsningsorienteret udvikler sig også kvalitativt over tid, ligesom den personlige indstilling og de aktiviteter, som skal understøtte udviklingen af denne, ikke er den samme først og sidst i uddannelsesforløbet. Denne udvikling er i det efterfølgende eksemplificeret med en række læringsmål, som udvikler sig over tid - fra grundskole og til afslutningen af uddannelsesforløbet. De efterfølgende eksempler skal vise, hvordan de fire dimensioner åbner for væsentlige nuancer i entreprenørskabsundervisningen, og de illustrerer hvordan det tiltagende videns- og refleksionsniveau, som elever og studerende opnår igennem uddannelse, er en forudsætning for progressionsbevægelsen. Eksemplerne favner ikke alle læringsmål i alle uddannelsesmæssige kontekster, men tager udgangspunkt i en række centrale videns- og kompetenceområder baseret på de fire entreprenørielle dimensioner. ${ }^{3}$

\begin{tabular}{|c|c|c|}
\hline Handling: & Fra & Hen imod \\
\hline Iværksættelse & $\begin{array}{l}\text { Med støtte og vejledning } \\
\text { fra læreren kan elever } \\
\text { iværksætte mindre projek- } \\
\text { ter og aktiviteter. }\end{array}$ & $\begin{array}{l}\text { De studerende kan selv iværk- } \\
\text { sætte over en længere periode, } \\
\text { og på baggrund af modne } \\
\text { refleksioner skabe økonomisk, } \\
\text { social eller kulturel værdi. }\end{array}$ \\
\hline Værdiskabelse & $\begin{array}{l}\text { Eleverne kan skelne imel- } \\
\text { lem aktiviteter og løsnin- } \\
\text { ger, der skaber værdi for } \\
\text { andre og aktiviteter og } \\
\text { løsninger, der ikke gør det. }\end{array}$ & $\begin{array}{l}\text { De studerende kan føre egen } \\
\text { faglighed ind i værdiskabende } \\
\text { initiativer enten via egne virk- } \\
\text { somheder, i eksisterende or- } \\
\text { ganisationer eller som projekt- } \\
\text { team. }\end{array}$ \\
\hline Kommunikation & $\begin{array}{l}\text { Eleverne kan kommunike- } \\
\text { re mundtligt og producere } \\
\text { simpel skriftlig kommuni- } \\
\text { kation. }\end{array}$ & $\begin{array}{l}\text { De studerende kan strategisk } \\
\text { variere deres kommunikation } \\
\text { mundtligt, skriftligt og digitalt } \\
\text { alt efter målgruppe og situati- } \\
\text { on. }\end{array}$ \\
\hline Samarbejde & $\begin{array}{l}\text { Eleverne kan samarbejde } \\
\text { og har en begyndende } \\
\text { bevidsthed om det net- } \\
\text { værk de indgår i. }\end{array}$ & $\begin{array}{l}\text { De studerende kan samarbejde } \\
\text { i forskellige sociale sammen- } \\
\text { hænge og refleksivt forholde } \\
\text { sig til disse. De studerende } \\
\text { kan danne og indgå i et team. } \\
\text { De kan anvende og udbygge } \\
\text { netværk professionelt. }\end{array}$ \\
\hline
\end{tabular}

\footnotetext{
${ }^{3}$ Kan i specifikke sammenhænge udvikles yderligere ud fra begreberne viden, færdigheder og kompetencer. Se fx kvalifikationsrammerne: Undervisningsministeriet. (2010). Den Danske Kvalifikationsramme for Livslang læring.(1. udg. 2. opl.); Europa Kommissionen. (2008). Forklaring af den europæiske referenceramme for kvalifikationer for livslang læring; European Commission. (2007). Key competences for lifelong learning. European Reference Framework.
} 


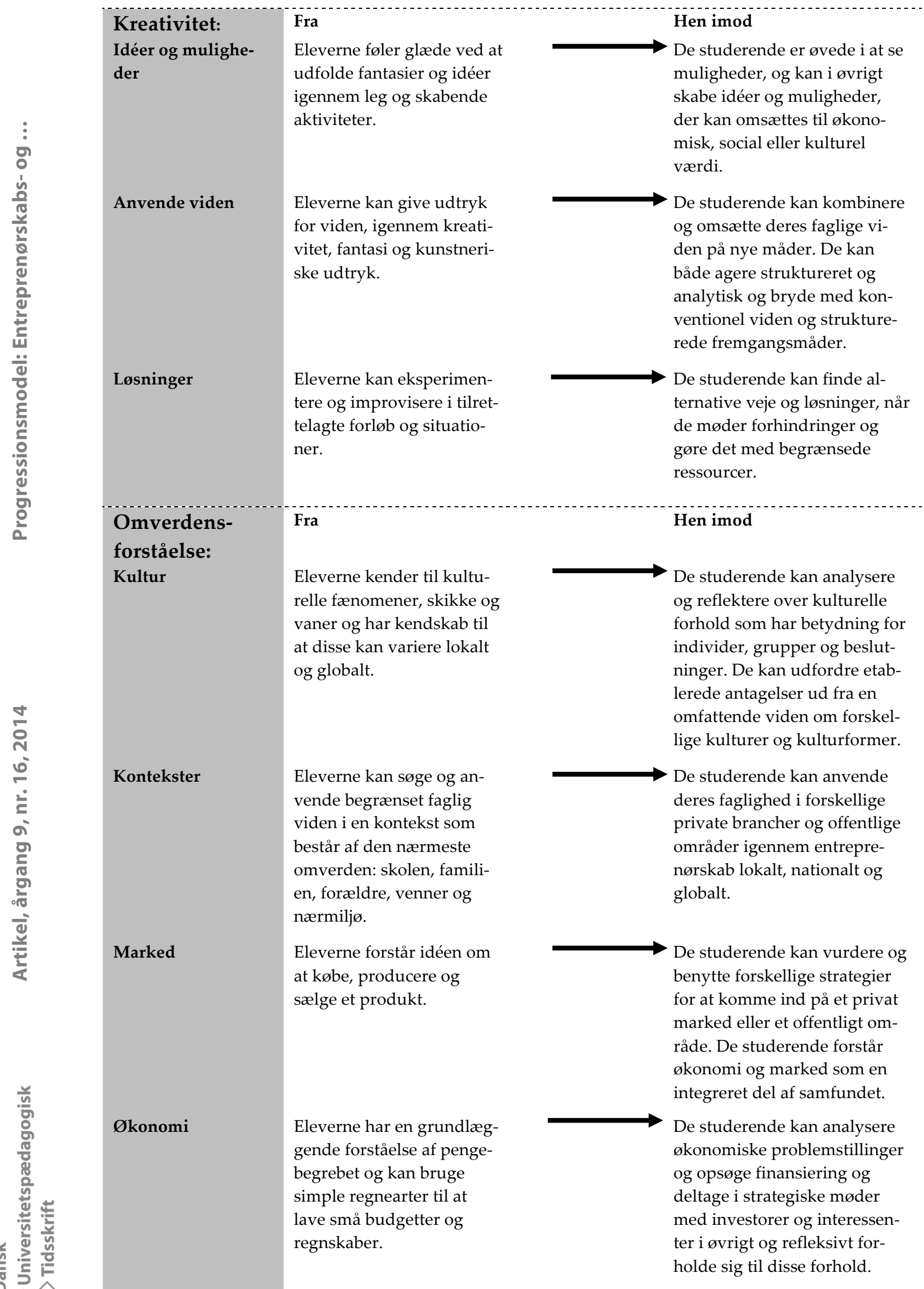




\begin{tabular}{|c|c|c|}
\hline $\begin{array}{l}\text { Personlig ind- } \\
\text { stilling: }\end{array}$ & Fra & Hen imod \\
\hline Tiltro til egne evner & $\begin{array}{l}\text { Eleverne har en grundlæg- } \\
\text { gende selvtillid og har } \\
\text { troen på, at de kan klare } \\
\text { stillede opgaver. De har en } \\
\text { begyndende tillid til, at de } \\
\text { gennem egne initiativer } \\
\text { kan påvirke deres egne } \\
\text { vilkår i verden. }\end{array}$ & $\begin{array}{l}\text { De studerende kan på bag- } \\
\text { grund af høj self-efficacy } \\
\text { håndtere komplekse situatio- } \\
\text { ner og skabe visioner, der } \\
\text { rækker ud i verden som vær- } \\
\text { diskabende scenarier. }\end{array}$ \\
\hline $\begin{array}{l}\text { Acceptere usikker- } \\
\text { hed }\end{array}$ & $\begin{array}{l}\text { Eleverne kan med støtte } \\
\text { fra lærere eller andre } \\
\text { voksne agere i situationer } \\
\text { præget af usikkerhed. }\end{array}$ & $\begin{array}{l}\text { De studerende kan agere i } \\
\text { situationer præget af usikker- } \\
\text { hed og håndtere risici. } \\
\text { De kan forholde sig refleksivt } \\
\text { til risici og handlinger relateret } \\
\text { hertil. }\end{array}$ \\
\hline Turde fejle & $\begin{array}{l}\text { Eleverne kan acceptere, at } \\
\text { de selv og andre kan begå } \\
\text { fejl. }\end{array}$ & $\begin{array}{l}\text { De studerende kan anerkende } \\
\text { og lære af egne eventuelle fejl } \\
\text { og forholde sig refleksivt til } \\
\text { andres fejltagelser og succeser. }\end{array}$ \\
\hline Etisk forholden & $\begin{array}{l}\text { Eleverne kan grundlæg- } \\
\text { gende forholde sig til sim- } \\
\text { ple etiske problemstillinger } \\
\text { i omverden, og kan skelne } \\
\text { imellem gode og mindre } \\
\text { gode initiativer. }\end{array}$ & $\begin{array}{l}\text { De studerende kan på et højt } \\
\text { abstraktions- og refleksionsni- } \\
\text { veau forholde sig til etiske } \\
\text { problemstillinger i forhold til } \\
\text { faglig viden, og forandrende } \\
\text { handlinger i forhold til kultur, } \\
\text { demokrati og bæredygtighed i } \\
\text { en globaliseret verden. }\end{array}$ \\
\hline
\end{tabular}

\section{Pædagogiske og didaktiske udfordringer}

Modellen og den viste progression i læringsmål giver mulighed for at etablere en samlet forståelse af entreprenørskabsundervisningen på mange niveauer i forskellige uddannelsesmæssige sammenhænge. Faglighed, indhold, didaktik og metoder kan således indarbejdes af de enkelte skoler og institutioner i en form, som er relevant $\mathrm{i}$ netop deres specifikke kontekst. Modellen fordrer dog, at alle fire entreprenørielle dimensioner er medtænkt i alle skoler og institutioner, og at elever og studerende gennem deres uddannelse får en række erfaringer med entreprenørielle og innovative processer. Dette er således en forudsætning, såfremt innovation og entreprenørskab skal danne en rød tråd igennem uddannelsessystemet.

Progressionsmodellen kan anvendes til undervisningsplanlægning og i den sammenhæng invitere til dialoger om, hvorvidt entreprenørskabsundervisning skal integreres i den eksisterende undervisning eller, hvorvidt nye former og praksisser skal udvikles. Dette gælder på overordnede niveauer i ministerier, kommuner og på den enkelte skole eller uddannelsesinstitution. Det gælder også for den enkelte underviser, der gennem modellen stilles den udfordring at sammentænke faglighed, innovation og entreprenørskab og sætte dette ind i en praksis, som sikrer elever og studerende værdifulde erfaringer, de kan bruge i fremtiden. 
Progressionsmodellens fokus på samspil imellem faglighed, entreprenørskab og entreprenørielle erfaringer fordrer et særligt læringssyn. Der er brug for, at elever og studerende får konkrete erfaringer med selv at være kreative, handlende i omverden, og at de erfaringer de får hermed, er af en sådan dybde og kvalitet, at de kan bruges som afsæt for fremtidig handling - også efter endt uddannelse. Det er samtidig centralt, at elever og studerende herigennem opbygger et positivt selvværd og etablerer en række succesfortællinger gennem uddannelsesforløbet. Med brugen af erfaringsbegrebet stilles der dermed en række krav til undervisningens indhold og form, som ikke alene kan være bygget op som en undervisercentreret form, hvor underviseren alene formidler viden om, hvad entreprenørskab og innovation er (Hannon, 2005). Undervisningen må bygges op, så elever og studerende også indgår i elev- og studentercentrede processer på baggrund af egne interesser, idéer og en blanding af underviserens og elevernes tilgang til fagligheden. Elever og studerende skaber i disse forløb aktivt værdi i verden med udgangspunkt i forskellige kernefagligheder. Entreprenørskab og innovation kan derfor både være hele fag i sig selv, men i lige så høj grad være indlejrede i eksisterende kernefaglige fag og vidensområder (Pittaway \& Edwards, 2012). Vi ser dette som en udfordring for undervisere uanset hvilket niveau og i hvilken kontekst, de møder elever og studerende. Derfor udestår en indsats i forhold til uddannelsen af nye undervisere og efteruddannelse af de nuværende, såfremt den kulturændring, som er et led i de nationale strategier, skal finde sted. ${ }^{4}$ De fire entreprenørielle dimensioner vil kunne danne afsæt og ramme for udviklingen af disse uddannelsesforløb og således sikre, at progressionen gennem uddannelsessystemet ikke bliver fragmenteret og isoleret til bestemte uddannelser eller perioder af uddannelsesforløbet.

Progressionsmodellens kobling mellem de fire entreprenørielle dimensioner, faglighed og erfaring, betyder, at der ikke findes ét enkelt undervisningsforløb, ét kursus eller én metode, som isoleret kan etablere en entreprenøriel dannelse. Det kræver en vedvarende indsats at lære at agere innovativt og entreprenørielt, uanset om man starter en virksomhed eller skaber social eller kulturel innovation.

Det er således et åbent spørgsmål om de undervisningsmaterialer og programmer, som i dag bruges i entreprenørskabsundervisningen, kan stå alene, eller om de skal suppleres med en række nye og endnu ikke udviklede modeller for, hvordan innovations- og entreprenørskabskompetencer kan tilegnes, læres og formidles. Pædagogisk og didaktisk kan progressionsmodellen danne ramme for at udvikle nye metoder og aktiviteter, som kan indgå i et mangfoldigt uddannelsessystem.

\footnotetext{
${ }^{4}$ Ministeriet for Forskning, Innovation og Videregående Uddannelse. (Dec. 2012). Danmark Løsningernes land. Styrket samarbejde og bedre rammer for innovation i virksomhederne.
} 
En særlig udfordring for modellen er de uddannelser, der har en af de fire dimensioner som deres faglige kernekompetence, fx 'marked' under 'omverdensforståelse', eller uddannelser, som har den kreative dimension som kernefaglighed. Modellen lægger op til, at den enkelte uddannelse i disse tilfælde kan lade sig inspirere af de øvrige dimensioner og se på, hvordan kompetencer og faglighed inden for én bestemt dimension kan spille sammen med de andre dimensioner.

En af udfordringerne ved at integrere innovation og entreprenørskab i undervisningssystemet er, at mange af de eksisterende udprøvningsformer ikke tilgodeser innovative og entreprenørielle kompetencer. Nærværende model kan være afsæt for en ny læringstaxonomi, der kan inspirere til nye former for test, prøver og eksamener. Samtidig kan disse prøver og eksamener danne ramme for værdifulde entreprenørielle erfaringer. Eksamener er i en sådan forståelse ikke blot en bagudrettet begivenhed men integrerede læringsforløb, som er rettet imod fremtidig entreprenøriel handling og mod etableringen af innovative kompetencer og entreprenøriel dannelse.

Nicolai Nybye er projektleder i Teamet for Videregående Uddannelser hos Fonden for Entreprenørskab - Young Enterprise. Han er cand.mag. fra Syddansk Universitet (SDU) med speciale i organisationskultur og lærende organisationer. Han har flere års undervisererfaring fra International Virksomhedskommunikation på SDU og erfaring som selvstændig og projektleder $i$ det private erhvervsliv.

Anders Rasmussen er teamleder i Grundskoleteamet hos Fonden for Entreprenørskab - Young Enterprise. Han er cand. pæed. i pædagogisk sociologi fra Aarhus Universitet med speciale i dannelse, modernitet og entreprenørskabspædagogik. Har undervist i efterskolen og været forstander i en årrække. Har lang erfaring med undervisning, ledelse, skoleudvikling og projektledelse.

\section{Litteratur}

Bandura, A. (Ed.) (1995). Self-efficacy in changing societies. New York: Cambridge University Press.

Baumann, Z. (2000). Liquid Modernity. Cambridge: Polity Press.

Blenker, P., Korsgaard, S., Neergaard, H. \& Thrane, C. (2011). The question we care about: Paradigms and progression in entrepreneurship education. Industry and Higher Education, 25(6), 417-427.

Byrge, C. \& Hansen, S. (2010). Den kreative platform i skolen. Selvstændighedsfonden.

Darsø, L. (2011). Innovationspædagogik. Kunsten at fremelske innovationskompetence (1. udg. 2. opl.). Frederiksberg: Samfundslitteratur.

De Bono, E. (1992). Serious creativity: Using the power of lateral thinking to create new ideas. New York: HarperCollins.

Detienne, D. R. \& Chandler, G. N. (2004). Opportunity identification and its role in the entrepreneurial classroom: A pedagogical 312 approach and empirical test. Academy of Management Learning and Education, 3(3), 242-257.

Dewey, J. (1916). Democracy and education. New York: Macmillan. 
Dewey J. (1933). How we think: A restatement of the relation of reflective thinking to the educative process. Boston, New York \& London: Heath.

Dyer, J., Gregersen, H. \& Christensen, C. (2011). The innovators DNA - Mastering the five skills of disruptive innovators. Boston, MA: Harvard Business Review Press.

Elkjær, B. (2009). Pragmatism: A learning theory for the future. In: Illeris, K.

(ed.): Contemporary theories of learning: Learning theorists ... in their own words. (s. 74-89). London \& New York: Routledge, Taylor \& Francis.

Europa Kommissionen. (2008). Forklaring af den europæiske referenceramme for kvalifikationer for livslang læring: http://ec.europa.eu/eqf/documentation _da.htm

European Commission. (2007). Key competences for lifelong learning. European Reference Framework.

Fayolle A. \& Gailly, B. (2008). From craft to science. Teaching models and learning processes in entrepreneurship education. Journal of European Industrial Training 32(7), 569-593.

Fiet, J. O. (2001a). The theoretical side of teaching entrepreneurship. Journal of Business Venturing, 16(1), 1-24.

Fiet, J. O. (2001b). The pedagogical side of entrepreneurship theory. Journal of Business Venturing, 16(2), 101-117.

Gibb, A. (2010). Towards the entrepreneurial university - entrepreneurship education as a lever for change. A National Council for Graduate Entrepreneurship (NCGE) report presenting and shaping the environment for graduate entrepreneurship in higher education: http://www.ncee.org.uk/publication/towards_the_entrepreneurial _university.pdf

Giddens, A. (1991). The consequences of modernity. Cambridge: Polity Press.

Guildford, J.: (1950). Creativity. American Psychologist, 5(9).

Hannon, P. D. (2005). Philosophies of enterprise and entrepreneurship education and challenges for higher education in the UK. International Journal of Entrepreneurship and Innovation, 6(2), 105-114.

Herlau, H. \& Tetzschner, H. (2004). Fra jobtager til jobmager. Frederiksberg: Forlaget Samfundslitteratur.

Honig, B. (2004). Entrepreneurship education: Toward a model of contingency-based business planning. Academy of Management Learning and Education, 3(3), 258-273.

Honig, B. \& Karlsson, T. (2004). Institutional forces and the written business plan. Journal of Management, 30(1), 29-48.

Kirketerp, A. L. (2010). Pædagogik og didaktik i entreprenørskabsundervisningen på de videregående uddannelser $i$ et foretagsomhedsperspektiv. Ph.d.-afhandling. IDEA. Institut for Entreprenørskab og relationsledelse, Syddansk Universitet.

Knight, F. H. (1921). Risk, uncertainty and profit. New York: Houghton Mifflin. 
Ministeriet for Forskning, Innovation og Videregående Uddannelse. (Dec. 2012).

Danmark Løsningernes land. Styrket samarbejde og bedre rammer for innovation $i$ virksomhederne: http://fivu.dk/publikationer/2012/filer-2012/danmarkloesningernes-land.pdf

Ministeriet for Videnskab, Teknologi og Udvikling. Økonomi- og Erhvervsministeriet. Undervisningsministeriet. Kulturministeriet. (Nov. 2009). Strategi for uddannelse i entrepenørskab: http://fivu.dk/publikationer/2010/filer-2010/strategi-forentreprenoerskab.pdf

Moberg, Vintergaard \& Vestergaard. (2013). Evaluating content dimensions in entrepreneurship education. In Entrepreneurship determinants: culture and capabilities. Eurostat Statistical books, European Union.

Neck, H. \& Greene, P. (2011). Entrepreneurship education. Known worlds and new frontiers. Journal of Small Business Management 49(1), s. 55-70.

Nielsen, S. L., Klyver, K., Evald, M. \& Bager, T. (2009). Entrepreneurship in theory and practice - Paradoxes in play. Odense: University Press of Southern Denmark.

Pajares, F. (1996). Current directions in self-efficacy research. Advances in motivation and achievement, 10, [M. Maehr \& P. R. Pintrich (Eds.) Greenwich, CT: JAI Press.] , s. 1-49.

Pittaway, L. \& Cope, J (2007). Entrepreneurship education. A systematic review of evidence. International Small Business Journal, 25(5), 479-510.

Pittaway, L. \& Edwards, C. (2012). Assessment: examining practice in entrepreneurship education. Education + Training, 54(8), $778-800$.

Sarasvathy, S. (2001). Causation and effectuation: toward a theoretical shift from economic inevitability to entrepreneurial contingency. The Academy of Management Review, 26(2), s. 234.

Sarasvathy, S. (2008). Effectuation: Elements of entrepreneurship expertise. Cheltenham, UK and Northampton, MA, USA: Edward Elgar Publishing.

Sarasvathy, S. \& Venkataraman, S., (2011). Entrepreneurship as method: Open questions for an entrepreneurial future. Entrepreneurship Theory and Practice .35(1), 113-135.

Schumpeter, J. [1911] (1934). The theory of economic development. Cambridge, MA: Harvard University Press.

Schumpeter, J. (1942). Capitalism, socialism and democracy. New York: Harper \& Row. Shane, S. \& Venkataraman, S. (2000). The promise of entrepreneurship as a field of research. Academy of Management Research Review, 25(1).

Swedberg, R. (ed.) (2000). Entrepreneurship: The social science view. Oxford: Oxford University Press.

Surlemont, E. (2009). Promoting entrepreneurship: A strategic move to get schools' cooperation in the promotion of entrepreneurship. In: Fayolle (ed.), Handbook of research in entrepreneurship education, vol. 2, Contextual Perspectives. Cheltenham, UK and Northampton, MA, USA: Edward Elgar. 
Tanggaard, L. (2008). Kreativitet skal læres. Når talent bliver til innovation. Aalborg: Aalborg Universitetsforlag.

Tanggaard, L (2010). Fornyelsens kunst - At skabe kreativitet i skolen. København: Akademisk Forlag.

Undervisningsministeriet. (2010). Den Danske Kvalifikationsramme for Livslang laring.(1.udg. 2. opl.).

Venkataraman, S., Sarasvathy, S. D., Dew, N. \& Forster, W. (2012). Whither the promise? Moving forward with entrepreneurship as a science of the artificial. Academy of Management Review, 37(1), 21-33.

Vestergaard, L., Jørgensen, C., Kejlstrup, S., Hakhverdyan, S. \& Christiansen, S.K. (red.) (2013). Entreprenørskab fra ABC til ph.d. Kortlagning af entreprenørskabsundervisning $i$ det danske uddannelsessystem. Fonden for Entreprenørskab - Young Enterprise: http://www.ffe-ye.dk/media/299942/fuld-rapport.pdf

West, M. (2004). The secrets of successful team management: How to lead a team to innovation, creativity and success. London: Duncan Baird Publishers. 